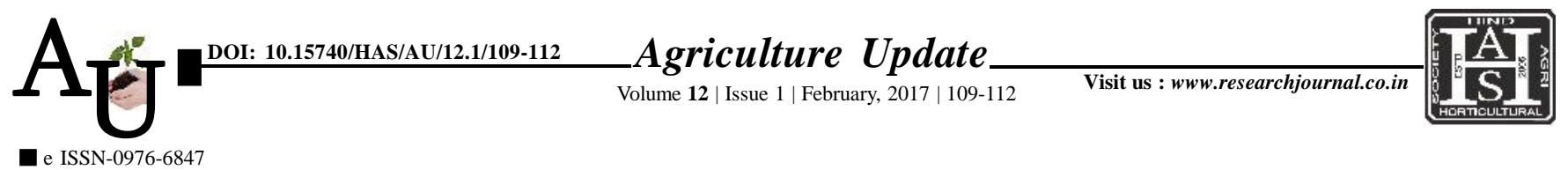

\title{
Research article: Gender dimensions and training needs of farm women in system of rice intensification in selected districts of Bihar state
}

\section{AMTUL WARIS}

Article Chronicle: Received :

29.11.2016;

Revised :

04.01.2017;

Accepted :

12.01.2017

KEY WORDS:

Women labour,

System of rice

intensification,

Training, Self-help

groups AU/12.1/109-112.
Author for correspondence :

\section{AMTUL WARIS}

ICAR-Indian Institute of Rice Research, Rajendra Nagar, HYDERABAD

(TELANGANA) INDIA

Email:amtul.waris

@gmail.com
SUMMARY : The system of rice intensification (SRI) has been introduced as an alternative system for growing rice with lesser inputs and water. Labour is one of the most crucial concerns in the adoption of SRI by farmers. SRI requires intensive labour inputs for land preparation, crop care, and water management, especially at the early phase of adoption. According to the latest census of Government of India (2011) 53 per cent of all male workers but 75 per cent of all female workers, and 85 per cent of all rural female workers, are in agriculture. The present study was, therefore, undertaken, to identify training needs of farm women in SRI cultivation and to analyze the drudgery perceived by farm women in traditional and SRI cultivation methods. Line sowing was felt as a new skill to be acquired and rated as highly skilful as farm women had to be careful and systematically plant within the square. There is immense scope of harnessing the potential of training members of women's self-help groups (SHG) to form a SRI task force to help in the wide spread adoption of SRI by farmers.

How to cite this article : Waris, Amtul (2017). Gender dimensions and training needs of farm women in system of rice intensification in selected districts of Bihar state. Agric. Update, 12(1): 109-112; DOI : 10.15740/HAS/ 